\title{
METODOLOGI DALAM KAJIAN PSIKOLOGI ISLAM
}

\author{
Siti Faridah \\ Fakultas Ushuluddin dan Humaniora \\ IAIN Antasari Banjarmasin
}

Diterima tanggal 4 Januari 2016 / Disetujui tanggal 15 Maret 2016

\begin{abstract}
:
Initially Islamic Psychology studies and development made many Muslim scholars were spellbound by western psychology theories. They used them as a tool to analyze all sorts of phenomenon Muslim society and give the solution. It is important to remember that the Islamic Psychology concept should be built by the Muslim psychologists their selves. However, the western psychology concept is not necessarily suitable with the needs and purposes in Islam area. Because of that, the writer is interested to discuss the Islamic Psychology Methodology. Hopefully, Islamic Psychology can be an alternative way to solve Muslim society psychological problem especially and all of human being in generally. There were three approaches used by classic Muslim scholars to discuss psychic problem. They are skeriptualis approach, falsafi/philosophy approach, and tasamnufi/Sufism approach. They are two studies in Islamic Psychology research; they are the theory and the method. Islam puts wabyu (divine revelation) as a religion paradigm which admits the existence of Allah in belief or in the implementation in the construction of science. Acsiologically, Islamic Psychology is built up to get the prosperity for human being. In epistemology, there is a relationship (nisbah) between mind and intuition. In ontology, it is for understanding buman being as sunnatullah. Thus, al-Qur'an is the main source. Both of positivism and rationalism ideologies have different perspectives in finding the truth. Positivism believes that there is only one sensory truth. It could be observed and approved by anyone. In other side, Rationalism admits three truths. They are imperisensual truth, imperi-logic truth, and imperi-ethic. Both of the ideologies do not admit metaphysical and transcendental matters. As the result, the Islamic Psychology research will come true. Finally, to build up an Islamic Psychology as a branch of science, we still have so many things to do.
\end{abstract}

Kata kunci: Psikologi Islam, Aliran Positivism, Aliran Rasionalisme

\section{Pendahuluan}

Pada awal perkembangan dan pengkajian psikologi Islam, banyak ilmuwan muslim yang terpesona dan mengagumi kehandalan teori-teori psikologi modern. Mereka menggunakan teori-teori tersebut sebagai pisau analisis untuk membedah berbagai fenomena umat Islam dan menawarkan solusinya. Cara yang dilakukan dengan menyesuaikan konsep Islam dengan konsep psikologi modern seperti yang dilakukan oleh Mustafa Zewar dan Zakiah Daradjat. ${ }^{1}$

Setelah terbitnya buku The Dilemma of Muslim Psychologist yang berisi tentang kritik terhadap penyiplakan besar-besaran oleh ilmuwan muslim terhadap teori psikologi modern, maka ilmuwan muslimpun mulai kritis terhadap sejumlah perbedaan dan pertentangan antara psikologi dan Islam. Buku ini mengingatkan psikolog muslim untuk tidak begitu saja mengikuti dan mempergunakan teori yang tidak sesuai dengan Islam. ${ }^{2}$ Kritik ini memunculkan kesadaran di kalangan ilmuwan muslim untuk merumuskan dan melahirkan konsep psikologi yang berwawasan Islam dengan berdasarkan Alquran dan Hadis, menggali khazanah pemikiran muslim klasik, dan mensintesiskan pandangan psikologi Barat modern dengan konsep Islam. ${ }^{3}$

Bagaimana sebenarnya teori psikologi Islami? Apakah penelitian yang menggunakan teori barat dengan subjek muslim bisa disebut dengan penelitian psikologi Islam? Apakah memang harus menggunakan istilah-istilah yang diambil dari Alquran dan Hadis baru bisa disebut penelitian psikologi Islam?

Dalam hal penelitian banyak pula masalah yang muncul, terutama dalam menentukan metode yang tepat untuk mengkaji masalah kejiwaan yang terjadi. Hal ini sangat penting mengingat konsep psikologi Islam

${ }^{1}$ Malik B. Badri, Dilema psikologi Muslim, terj. Siti Zainab Luxfiati (Jakarta: Pustaka Firdaus, 1995), h. 48. Lihat juga: Zakiah Daradjat dalam Ilmu Jiwa Agama (Jakarta: Bulan Bintang, 1993), cet. 14, 39.

${ }^{2}$ Fuad Nashori, Psikologi Islami Agenda Menuju Aksi (Yogyakarta: Pustaka Pelajar, 1997), 21.

${ }^{3}$ Fuad Nashori, Psikologi Islami, 24-35. 
harus dibangun sendiri oleh psikolog muslim, sedangkan konsep psikologi Barat belum tentu sesuai dengan kebutuhan dan tujuan di lingkungan Islam. Untuk itulah penulis tertarik untuk membicarakan metodologi psikologi Islam dengan harapan psikologi Islam dapat menjadi alternatif untuk menyelesaikan permasalahan kejiwaan umat Islam pada khususnya dan manusia pada umumnya.

\section{Pendekatan Kajian Kejiwaan Islam Klasik}

Sebelum membicarakan metode dalam kajian psikologi Islam, Baiknya kita bicarakan dulu pendekatan para tokoh intelektual Islam klasik di dalam mengkaji masalah jiwa. Para pengkaji jiwa pada masa klasik tersebut tidak dikenal sebagai ahli jiwa dan disiplin ilmunya tidak disebut dengan ilmu jiwa, tapi ilmu tafsir (mufassir), hadis (mubadditsin), filsafat Islam (filosof Islam), tasawuf (sufi) dan ilmu-ilmu keislaman lainnya. Beberapa pendekatan yang pernah mereka lakukan di dalam mengkaji jiwa adalah pendekatan skriptualis, pendekatan falsafi/filosofis dan pendekatan tasammufi/sufistik. ${ }^{4}$

1. Pendekatan skriptualis. Pendekatan skriptualis adalah pengkajian jiwa yang didasarkan pada teks-teks Alquran atau hadis. Lafal-lafal yang terkandung di dalamnya merupakan petunjuk (dilalab) yang sudah dianggap jelas (sharib). Asumsi filosofisnya adalah bahwa Allah menciptakan nafs manusia dengan segala hukum psikologisnya. Prosedur metodologinya dapat ditempuh dengan empat cara yaitu tafsir maudhu'i (tematis), tafsir tablili (analisis), tafsir maqarin (perbandingan) dan tafsir ijmali (global). Dalam terminologi Ilmu Tafsir, pendekatan skriptualis sama dengan aliran al-manqûl.

2. Pendekatan falsafi/filosofis. Pendekatan falsafi/filosofis adalah pendekatan yang mengacu kepada akal (burban). Pendekatan falsafi dalam pengkajian jiwa ini didasarkan atas prosedur berpikir spekulatif (sistematis, radikal dan universal yang didukung akal sehat). Pendekatan ini mengutamakan akal tanpa meninggalkan nash, hanya cara memahaminya dengan mengambil makna esensi yang tersirat di dalamnya. Jika terjadi pertentangan antara akal dan wahyu, berarti akal belum mampu menangkap pesan nash tadi. Untuk itu diperlukan interpretasi filosofis (ta'wi t) terhadap lafal nash. Dalam terminologi Ilmu Tafsir pendekatan falsafi identik dengan aliran ma'qûl.

3. Pendekatan tasawmufis/sufistik. Pendekatan tasawmufis/sufistik adalah pendekatan yang mengacu kepada intuisi (irfan). Pendekatan sufistik dalam pengkajian psikologi Islam didasarkan pada prosedur intuitif (alhadsiyah), ilham dan cita-cita (al-zauqiah) dengan cara menajamkan struktur kalbu melalui proses penyucian diri (tarkiyah al-nafs) untuk membuka tabir (bijab) yang menjadi penghalang ilmu-ilmu Allah dengan jiwa manusia, hingga memperoleh ketersingkapan (al-kasyaf) dan mampu mengungkapkan hakikat jiwa sesungguhnya. Dalam terminologi ilmu tafsir pendekatan sufistik disebut juga dengan Itsari.

\section{Kajian Kejiwaan dalam Islam}

Setelah kebangkitan Islam, pada tahun 1978 para pemerhati dan pengkaji masalah kejiwaan berkumpul di Universitas Riyad Arab Saudi dengan kegiatan International Syimposium on Psychology and Islam. Gerakan ini berlanjut ketika Malik B. Badri (psikolog Afrika), menerbitkan buku The Dilemma of Muslem Psikologys pada tahun 1979. ${ }^{5}$ Sejak itu kajian kejiwaan dalam Islam terus berkembang.

Dalam kajian atau penelitian psikologi Islam, ada dua hal penting yang harus diperhatikan, yaitu masalah teori dan masalah metode. Idealnya, teori yang dipergunakan berdasarkan pandangan dunia Islam. Menurut Fuad Abu Hatab (Guru Besar Psikologi Universitas A'in Syams Mesir), konsep psikologi harus dibangun sendiri oleh psikolog muslim, karena konsep psikologi para psikolog Barat tidak sesuai dengan kebutuhan dan tujuan di lingkungan Islam. ${ }^{6}$ Pendapat Abu Hatab sejalan dengan pendapat Sardar yang menyatakan bahwa bahwa islamisasi harus berangkat dari pandangan dunia (world view) yang islami dan paradigma keilmuannya, karena itu teori harus sejalan dengan ajaran Islam. Pandangan dunia (world view) Islam adalah keseluruhan bekerjanya alam semesta dan kehidupan manusia dalam sunnatullab yang tertulis dalam ayat kauniyah dan kauliyah. ${ }^{7}$

Menurut Bastaman ada enam proses islamisasi teori psikologi Barat, yaitu:

${ }^{4}$ Abdul Mudjib dan Jusuf Mudzakir, Nuansa-Nuansa Psikologi Islam (Jakarta: RajaGrafindo Persada, 200), 15.

${ }^{5}$ Fuad Nashori, Psikologi Islami, 1.

${ }^{6}$ Ilmu dalam peradaban Barat sekuler diklaim bebas nilai, sebenarnya tidak bebas nilai. Ia hanya bebas dari nilai agama dam ketuhanan, karena secara fisik manusia lahir di tengah agama, kepercayaan, nilai dan kultur yang menguasai masyarakat. Lihat: Muhammad Izzuddin Taufiq, Panduan Lengkap dan Praktis Psikologi Islam (Jakarta: Gema Insani, 2006), 17.

${ }^{7}$ Sardar Z., Menjawab Tantangan Abad 21, terj. A. E. Priyono \& Ilham Yahya (Bandung: Mizan, 1986), 11. 
1. Similarisasi, yaitu menyamakan begitu saja konsep psikologi Barat dengan konsep-konsep kejiwaan dalam Islam.

2. Paralesasi, yaitu menganggap paralel konsep-konsep psikologi Barat dengan konsep-konsep ajaran-ajaran Islam yang dikarenakan kemiripan konotasinya.

3. Komplementasi, yaitu menganggap antara sains dan ajaran Islam saling mengisi dan memperkuat dengan tetap mempertahankan eksistensinya.

4. Komparasi, yaitu memperbandingkan antara teori psikologi Barat dengan ajaran-ajaran Islam dengan tujuan untuk mencari titik temu di antara keduanya.

5. Induktivikasi, yaitu upaya menterjemahkan temuan empirik kejiwaan menjadi teori metafisik, kemudian menghubungkan hasil temuan tersebut dengan ajaran Islam.

6. Verifikasi, yaitu mengungkapkan hasil temuan ilmiah dalam bidang kejiwaan yang membuktikan kebenaran ajaran Islam. ${ }^{8}$

Terdapat empat pola dalam pengkajian psikologi Islam, keempat pola tersebut adalah:

1. Psikologi menjelaskan Islam (ajaran Islam dan umat Islam). Pada pola ini memperlihatkan bahwa pada tarap tertentu teori-teori psikologi memiliki keunggulan di dalam menjelaskan dan memprediksi tingkah laku manusia, namun sering terjadi bias, seperti teori John S. Carrol tentang mengapa seseorang melakukan kejahatan. ${ }^{9}$

2. Perbandingan psikologi dengan Islam. Pada pola ini terjadi usaha memperbandingkan konsep-konsep manusia, kepribadian dan lain-lain antara psikologi dengan Islam. Seperti yang dilakukan Dawam Rahardjo. ${ }^{10}$ Metode ini dapat dipakai bila konsep Islam telah dirumuskan secara matang. Kalau tidak, dikhawatirkan terjadi proses similarisasi (menyamakan begitu saja). Hal ini tentu tidak boleh dilakukan.

3. Penilaian Islam terhadap psikologi. Islam adalah sumber pedoman kehidupan manusia. Banyak cerita dan konsep manusia dalam Alquran. Islam dapat digunakan sebagai pisau analisis untuk membedah konsepkonsep psikologi modern seperti yang dilakukan Malik B. Badri. ${ }^{11}$ Manusia diberi kebebasan dengan tuntunan agama, akal dan hati nuraninya, Sayangnya sering tidak proporsional dalam mengkritisi psikologi.

4. Membangun konsep psikologi berdasarkan Islam. Pola keempat adalah upaya yang paling orisinal dan menentang, karena ada usaha untuk menghadirkan perspektif baru dalam memahami manusia secara psikologis. Lahirlah konsep fitrah manusia, konsep ruh, akal, kalbu, nafsu dan lain-lain. Pada pola ini psikologi Islam diartikan sebagai studi tentang jiwa manusia yang didasarkan pada pandangan dunia Islam.

Berdasarkan pola-pola di atas, dirumuskanlah psikologi Islam, yaitu:

1. Perumusan psikologi Islam berdasarkan pandangan dunia Islam. Merumuskan psikologi berdasarkan pandangan dunia Islam dianggap penting dalam rangka mengenal lebih jauh jiwa manusia serta kebutuhan ilmiah untuk membangun peradaban dan kemanusiaan. Disiplin psikologi Islam membantu seseorang untuk memahami ekspresi diri, aktualisasi diri, konsep diri, harga diri, kesadaran diri, kontol diri dan evaluasi diri. Jika ditemukan penyimpangan perilaku, psikologi Islam menawarkan berbagai konsep bernuansa ilahiyah untuk mengarahkan kualitas hidup yang lebih baik. Melalui cara ini, beberapa pola perumusan psikologi Islam yang mendekati kebenaran tertinggi, yaitu:

${ }^{8}$ Rafy Sapuri, Psikologi Islam, Tuntunan Jiwa Manusia Modern (Jakarta: Rajawali Pers, 2009), 37-39.

${ }^{9}$ Menurut John S. Carrol: seseorang melakukan kejahatan atau tidak berdasarkan pertimbangan sejauh mana kesuksesan yang diperoleh, besar kecilnya keuntungan dan kemungkinan gagal. Lihat: Djamaluddin Ancok \& Fuad Nashori Suroso, Psikologi Islami,: Solusi Islam atas problem-problem Psikologi (Yogyakarta: Pustaka Pelajar, 1994), 12 .

${ }^{10}$ Contoh: perbandingan antara Imam al-Ghazali dengan S. Freud tentang struktur kepribadian manusia. Bagi al-Ghazali, struktur kepribadian manusia itu terdiri dari nafs al-mutmainnah, nafs al-lawwanah dan nafs al-Ammarah, sedang bagi Freud struktur kepribadian itu terdiri dari super ego, ego, id. Dawam Rahardjo menyamakan istilah super ego dengan nafs al-mutmainnah, ego dengan nafs al-lawwanah dan id dengan nafs al-ammarah. .Lihat: Dawam Rahardjo, Ensiklopedia Al-Quran, Tafsir Sosial Berdasarkan Konsep-Konsep Kunci (Jakarta: Paramadina, 1996), 265.

${ }^{11}$ Psikoanalisis terlalu deterministik (menyederhanakan) perkembangan kehidupan manusia, bahwa manusia sangat ditentukan oleh pengalaman masa lalunya, terutama usia 0-5 th. Lihat: Malik B. Badri,, Dilemma psikologi Muslim, 43. 
2. Perumusan psikologi dengan bertitik tolak dari Alquran dan Hadis. Perumusan psikologi dengan bertitik tolak dari Alquran dan Hadis diawali dengan pertama, bertitik tolak dari istilah-istilah kejiwaan dalam Alquran dan Hadis sebagai rujukan utama. Kedua, memahami konsep keseluruhan Alquran dan Hadis, tentang tema tertentu seputar manusia. Misalnya, bagaimana pandangan Alquran ataupun Hadis tentang hakekat dan proses penciptaan manusia.

3. Perumusan psikologi bertolak dari khazanah ilmu keislaman klasik. Konsep-konsep Psikologi Islam dari khazanah ilmu keislaman tradisional itu secara tidak langsung dikembangkan dari Alquran dan Hadis. Hasil pemikiran mereka tentang manusia di berbagai bidang, seperti konsep manusia sempurna (insan kami) alJilli, Nuruddin al-Raniry, Muhammad Iqbal, al-Ghazali dll. Pola ini sangat strategis dilakukan dengan alasan: 1). Capaian pemikiran dari ilmuwan muslim terutama zaman klasik, diakui sebagai hasil pemikiran yang mendalam. 2). Salah satu tugas kita adalah menyambung hasil pemikiran mereka dengan usaha merumuskan Psikologi Islam dalam kontek kekinian.

4. Perumusan Psikologi Islam dengan inspirasi dari khazanah psikologi modern dan membahasnya dengan kerangka Alquran dan Hadis. Cara ini telah dilakukan oleh Malik B. Badri dalam mengungkap konsep tafakkur. ${ }^{12}$ Keunggulan cara ketiga ini adalah ide-ide yang digali dalam Alquran dan Hadis relevan dengan konsep-konsep psikologi Modern.

5. Merumuskan konsep manusia berdasarkan pribadi yang hidup di dalam Islam. ${ }^{13}$

6. Perumusan teori-teori spesifik. Perumusan teori spesifik seperti tentang kecenderungan alami manusia kepada kebaikan dan kebenaran, kebebasan manusia, perilaku riilnya, dan lain-lain.

7. Perumusan metodologi dan penyelenggaraan riset. Pandangan dunia Islam tentang realitas meliputi material, psikhis dan spiritual, sedangkan wilayahnya terdiri dari wilayah yang teramati, wilayah yang terpikirkan dan wilayah yang tak terpikirkan, karenanya penggunaan indra, akal, hati dan wahyu adalah konsekwensi logisnya.

\section{Metode Penelitian dalam Psikologi Islam}

Islam berbeda dengan Filsafat Yunani kono dan Filsafat Barat di dalam pencarian kebenaran. Masingmasing memiliki penekanan yang berbeda dari aspek ontologi, epistimologi maupun aksiologi. Menurut Noeng Muhadjir, Filsafat Yunani kono menekankan aspek ontologi dengan mengoptimalkan nalar untuk memahami substansi yang menjadi objek pemikiran kognisi maupun realitas inderawi dengan metode spekulatif. Sedang ilmu pengetahuan Barat menekankan dimensi epistimologi sebagai alat mencari kebenaran. Asumsi dasarnya adalah kebenaran sangat tergantung kepada metode ilmiah yang dipakai, Dengan demikian, kualitas metode mencerminkan kualitas kebenaran yang diperoleh. ${ }^{14}$

Dalam konteks Islam, aksiologi merupakan weltanschaung (pandangan hidup) yang berfungsi sebagai landasan di dalam mengkonstruksi fakta. Dalam pandangan Islam, ilmu dan sistem nilai tidak dapat dipisahkan, karena ilmu merupakan fungsionalisasi ajaran wahyu. Secara aksiologi psikologi Islam bersumber dari Alquran yang berbunyi:

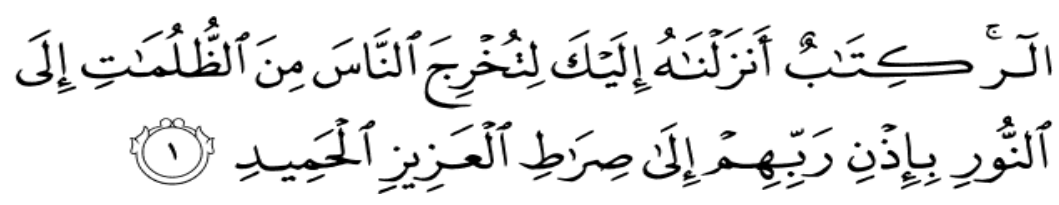

"(Ini adalab) Kitab yang kami turunkan kepadamu supaya kamu mengeluarkan manusia dari gelap gulita kepada cahaya terang benderang dengan izin tuban mereka, (yaitu) menuju jalan Tuban Yang Maba Perkasa lagi Maha Terpuji”. (QS. Ibrahim/14: 1).

${ }^{12}$ Dengan menggunakan inspirasi kata proses berpikir dalam khazanah Psikologi Modern beliau membentangkan pandangan Alquran, Hadis dan ulama Islam tentang tafakkur dengan membuat kerangka baru, beliau menyatakan tafak.kur sebagai cara menuju satu tingkatan ketika di dalam hati manusia hanya ada cinta, harapan, dan ketundukan kepada Allah saja. Lihat: Malik B. Badri, Tafakur: Perspektif Psikologi Islam, Terj. Usman Shihab Husnan (Bandung: Remaja Rosdakarya, 1996).

${ }^{13}$ Fuad Nashori, Agenda Psikologi Islam Yogyakarta: Pustaka Pelajar, 2002), 62-75.

${ }^{14}$ Rif at Syauqi Nawawi, et. al., Metodologi Psikologi Islami (Yogyakarta, Pustaka Pelajar, 2000), 105. 
Berdasarkan ayat di atas nampaklah bahwa Islam meletakkan wahyu sebagai paradigma agama yang mengakui eksistensi Allah dalam keyakinan maupun aplikasinya dalam konstruksi ilmu pengetahuan. Islam menolak sains untuk sains (science for science), namun melibatkan moralitas di dalam mencari kebenaran ilmu. Maka secara oksiologi psikologi Islam dibangun dengan tujuan untuk menghasilkan kesejahteraan bagi seluruh umat (rabmat li al-'alamin).

Secara epistemologi psikologi Islam membicarakan apa yang dapat diketehui dan bagaimana cara mengetabuinya. Itu sebabnya, pemaknaan aksiologik sangat berperan untuk menentukan kebenaran epistimologik. ${ }^{15}$ Maka dasar epistimologinya adalah hubungan (nisbab) akal dan intuisi. Psikologi Islam adalah ilmu yang terintegrasi dengan pola pendekatan disiplin ilmu keislaman lainnya yang memiliki kekhasan secara paradigma dan epistimologi. Perbedaan-nya dengan metodologi ilmiah tidaklah mengurangi keilmiahan-nya bila kita mengkritisinya dengan berpedoman kepada paradigma dan epistimologi sendiri.

Secara ontologi, untuk memahami manusia sesuai sunnatullah. Maka Alquran sebagai sumber ilmu pengetahuanlah yang paling dapat diandalkan. Ayat-ayat yang membicarakan terma-terma seperti insan, basyar, nafs, aql, ruh, qalb dapat dijadikan rujukan. Untuk patokannya, sejauh mana metodologi itu dapat mengejar makna dan esensi, bukan hanya gejala. Dengan alasan itu Noeng Muhajir menyatakan bahwa psikologi Islam bermakna sebagai psikologi yang menemukan landasan filsafat ilmunya pada nilai-nilai Islam. ${ }^{16}$

Psikologi Islam merupakan bagian dari tasawuf, oleh karena itu metodologi tasawuf dapat pula dijadikan patokan untuk menentukan metodologi psikologi Islam. Sebagai contoh metodologi secara konseptual pada tasawuf al-Ghazali dalam kitab Ihya Ulum al-Din yang secara aksiologi bersumber dari wahyu, dasar epistimologinya adalah nisbah akal dan intuisi, dan dasar ontologinya adalah terma-terma seperti al-aql, al-nur dan etika/moral. ${ }^{17}$

Dalam mencari kebenaran, aliran positivisme dan aliran rasionalisme memiliki cara pandang yang berbeda satu sama lainnya. Aliran positivisme hanya mengakui satu kebenaran inderawi/sensual yang dapat diamati dan dibuktikan oleh siapa saja, Di sisi lain, aliran rasionalisme mengakui tiga kebenaran, yaitu kebenaran imperi-sensual, kebenaran imperi-logik dan kebenaran imperi-etik. Keduanya tidak mengakui halhal yang bersifat metaphisik dan transcendental. Dengan cara pandang kedua aliran di atas terhadap manusia, dapat kita bayangkan kemungkinan pecahnya kepribadian seseorang yang di satu sisi mempelajari filsafat rasionalistik ataupun positivistik dan di sisi lain diajarkan agama yang padat dengan kebenaran transendental, Paradigma semacam ini dikhawatirkan dapat mengerosikan keimanan. Oleh karena itu, sangat bijak cara yang ditempuh dalam perkembangan filsafat ilmu yang membuka kesempatan untuk mengintegrasikan antara ilmu dan wahyu dalam kebenaran yang bersifat monistik, tanpa dikhotomi, sebab keduanya sama-sama memberikan kontribusi kepada manusia di dalam mencari kebenaran.

Sebenarnya realitas tingkah laku manusia itu beragam. Ada yang mudah dijelaskan secara empirisensual, ada yang dapat dimengerti dengan penjelasan logik, ada yang memerlukan penjelasan etik. Kebenaran ilmu pengetahuan Islam tidak selamanya harus dicari, karena ada hal-hal yang perlu disyukuri sebagai rahmat dan ada pula hal-hal yang hanya dapat dihadapi dengan sabar dan dipahami dengan mengambil hikmahnya.

Dalam psikologi Islam kebenaran bersifat integratif, tetapi juga bersifat probabilistik. Walaupun usaha manusia mendapatkan kebenaran tercapai, namun pada hakikatnya kebenaran itu hanya bersifat probabilistik, maka usaha manusia harus selalu melewati proses yang panjang tanpa akhir untuk menuju kebenaran mutlak yang hanya milik Allah. Apabila kebenaran yang dicapai manusia berbeda dengan kebenaran mutlak Allah, maka kebenaran yang dicapai oleh akal berarti belum mampu untuk mencapai kebenaran mutlak Allah. Dengan demikian, maka pemahaman tentang jiwa manusia dengan melalui usaha-usaha ilmiah akan selalu mungkin nilai benar dan mungkin nilai salah.

Selain itu, tampilan kebenaran psikologi Islam dapat bersifat aspektif atau menonjol pada tataran tertentu, namun pada kasus lain, aspek yang tampil bisa saja berbeda. Keadan ini bukan berarti kebenaran psikologik itu banyak. Untuk itu Noeng Muhadjir menawarkan konsep monisme multifaset. Di mana kebenaran dan realitas tingkah laku manusia yang tunggal (monistik), menjadi beragam karena tampilan. ${ }^{18}$

Cara pandang yang mengakui bermacam-macam tampilan ini, membuat kita lebih arif dan bijak di dalam menentukan metodologi yang tepat dan sesuai dengan karakteristik dari tampilan obyeknya. Contoh,

${ }^{15}$ Rif at Syauqi Nawawi, et. al., Metodologi Psikologi Islami, 106-107.

${ }^{16}$ Rif at Syauqi Nawawi, et. al., Metodologi Psikologi Islami, 110.

${ }^{17}$ M. Amin Abdullah Syukur dan Masyharuddin, Intelektualisme Tasawuf,Studi Intelektualisme Tasawnf Al-Ghazali (Yogyakarta: Pustaka Pelajar, 2002), 170-209.

${ }^{18}$ Rif at Syauqi Nawawi, et. al, Rif at Syauqi Nawawi, et. al., Metodologi Psikologi Islami, 111. 
metodologi positivistik yang kuantitatif-statistik, sesuai dengan karakter objek yang emperi-sensual. Metodologi rasionalistik dapat digunakan untuk membangun konsep teoritik-logik. Metodologi realisticmetaphisik bila ingin melakukan studi keagamaan yang mengakui wahyu Alquran sebagai sumber kebenaran.

Ada beberapa metode yang ditawarkan oleh para ahli dalam perumusan, penelitian dan pengembangan psikologi Islam, yaitu:

\section{Metode-Metode dalam Perumusan Psikologi Islam}

Adapun metode-metode dalam perumusan psikologi Islam meliputi: metode keyakinan, metode rasionalisasi, integrasi metode keyakinan dengan rasionalisasi, metode otoritas dan metode instuisi. ${ }^{19}$ Metode ini disebut juga dengan metode non ilmiah.

1. Metode Keyakinan (method of tenacity). Dalam metode keyakinan seseorang harus meyakini betul tentang kebenaran sesuatu yang bersumber dari Alquran dan Hadis dengan asumsi dasar bahwa Allah adalah pencipta kehidupan yang mengetahui seluk beluk dari makhluk ciptaan-Nya. Inilah ciri khas psikologi Islam yang menempatkan wahyu di atas rasio. Pandangan seperti ini banyak mendapat sanggahan baik dari kalangan ilmuwan non-muslim, maupun dari kalangan ilmuwan muslim sendiri. Mereka beranggapan bahwa wahyu dan ilmu adalah sesuatu yang berbeda penggunaannya dan tidak dapat dipersandingkan, namun banyak ilmuwan kontemporer yang menggunakan metode keyakinan sebagai salah satu metode dalam penelitiannya. Mereka menggunakan ayat Alquran sebagai sumber pengetahuan. Problem utama adalah dapat tidaknya mengukur aspek yang menyentuh "wilayah keimanan". Ada 3 pendapat, yaitu: a). Menolak dengan alasan bahwa iman adalah aspek spiritual yang bersifat doktrin, diterima secara apriori, irrasional, subyektif, tidak logis. Mengukur iman berarti mengukur ketidaklogisan. b). Menerima dengan kerangka materialistik, mereka adalah ilmuwan perilaku dalam psikologi Agama dengan pandangan positivisme. Akibatnya semua aspek iman disamakan dengan asfek perilaku dan dibedah dari sudut pandang obyektif. Padahal iman berhubungan dengan yang gaib, aspek rahasia dan hidayah kebenaran. c). Menggabungkan keduanya. Bagi mereka iman memiliki aspek ilahiah dan subyektik. Iman eksoteris yang memiliki ranah obyentif yang dapat diukur, yaitu kognitif (aqli), efektif (zawuq) dan psikomotorik (amal) dapat diukur berdasarkan aspek-aspek kemanusiaan (Q.S. al-Mumtahanah/60:10), dan ada iman esoteris yang bersifat rahasia dan wewenang pemberi hidayah. ${ }^{20}$

2. Metode integrasi keyakinan dengan rasionalisasi. Psikologi Islam berpandangan bahwa manusia harus mempergunakan rasio secara optimal dengan menyadari keterbatasannya. Penggunaan akal ini sesuai dengan perintah Allah dalam Alquran. Sebagai contoh, ketika seorang berusaha memahami suatu realitas, sebaiknya mempergunakan rasionya sambil tetap meyakini bahwa ada keterbatasan rasio dan adanya keyakinan bahwa wahyu Allah di atas segalanya.

3. Metode otoritas (method of authority). Menyandarkan kepercayaan kepada orang yang mempunyai banyak pengetahuan dalam bidang tertentu seperti Tafsir bi al-Ma'tsur yang merujuk kepada penjelasan Rasulullah melalui hadis-hadisnya, para sahabat dan ulama. Psikologi Islam dapat melakukan hal itu untuk mengetahui realitas di balik alam nyata.

4. Metode intuisi. Pendayagunaan kalbu dapat membantu untuk mengetahui apa yang ada di dalam diri manusia. Metode eksperimen spritual ini memerlukan perlakuan tertentu secara ruhani untuk mengetahui dampaknya. Contohnya, membiasakan salat malam dengan berusaha mengetahui bagaimana rasa hati terhadap Allah dengan kebiasaan tersebut. Dengan cara ini akan terbukalah penghalang (kassful mahjub) di mana seseorang akan mampu memahami realitas yang tak terjangkau oleh panca indera, seperti peristiwa Nabi Khidr yang mampu mengetahui seorang anak yang apabila dibiarkan hidup maka akan menjadi durhaka, karena itulah lalu beliau membunuh anak tersebut. Peristiwa ini dapat terjadi pada seorang nabi, orang beriman dan shaleh, serta di kalangan sufi peristiwa semacam ini menjadi sesuatu yang sangat mungkin dilaksanakan. 


\section{Metode Pengembangan Psikologi Islam}

Metode pengembangan psikologi Islam yang dimaksud adalah kajian tentang konsep-konsep yang berkaitan dengan jiwa dalam khazanah keislaman dengan jenis penelitian kepustakaan. Metode dimaksud adalah:

1. Metode pragmatis. Metode pragmatis adalah pengkajian dan pengembangan psikologi Islam yang mengutamakan aspek praktis dan kegunaannya. Metode ini ditransfer dari kerangka teori Barat kontemporer yang dilegalisasi dan dijustifikasi dengan nash, sehingga bernuansa islami. ${ }^{21}$ Metode pragmatis bersifat responsif, akumudatif, toleran, efektif dan efisien untuk membangun psikologi Islam. Kekurangannya terletak pada kekhawatiran terseretnya psikologi Islam kepada frame Barat skuler yang bertentangan dengan kode etik ilmiah-Qurani. ${ }^{22}$ Perbedaan paradigma dan proses penyeleksian yang kurang ketat dapat membawa psikologi Islam bercorak skuler. Malik B. Badri dalam bukunya The Dilemma of Muslim Psychologits menyatakan bahwa ketidakselektifan psikolog muslim dapat menyebabkan mereka mengikuti cara hidup dan cara pandang (Yahudi-Kristen) yang tidak islami. ${ }^{23}$ Rasulullah dalam Hadis beliau bahkan meramalkan cara ini: ..."bahkan jika mereka masuk ke dalam lubang biawak pun, orang Islam tanpa pikir panjang akan mengikutinya." ${ }^{24}$ Contohnya, kecenderung menyamakan istilah super ego dengan al-nafs al-muthmainnah, ego dengan al-nafs al-lawwamah dan id dengan al-nafs al-ammarah, ${ }^{25}$ yang memiliki terma dan asumsi yang berbeda. Konsep al-nafs diasumsikan dari paradigma teosentris, sedang id, ego dan super ego diasumsi dari paradigma antroposentris yang menafikan makna keberagamaan dan bertuhan. Untuk menghindari hal ini perlu mengikuti langkah-langkah yang ditawarkan oleh Ismail Raji al-Faruqi. ${ }^{26}$

2. Metode Idealistik. Metode yang mengutamakan penggalian psikologi Islam dari ajaran Islam. Metode ini menggunakan pola deduktif dengan cara menggali premis mayor sebagai postulasi yang digali dari nash dan dijadikan "kebenaran universal" untuk menggali premis minornya. Menurut Elmira N. Sumintardja, objek formal psikologi Islam adalah konsep manusia berdasarkan Alquran dan Hadis yang pemahamannya hanya dapat diperoleh dengan metode Ilmu Tafsir dan Ushul Fiqh. Pertimbangan adalah bahwa manusia dapat menggunakan akal untuk proses pemahamannya. Kebenaran substansi dapat dicapai bila manusia meyakini bahwa ilmu diberikan Allah kepadanya (naqliyah) dan pengetahuan yang digali melalui akal sehatnya (aqliyah). ${ }^{27}$

a. Metode Ilmu Tafsir. Pendekatan dalam Ilmu Tafsir dapat dilakukan untuk mengkaji masalah kejiwaan manusia.

1) Tafsir Maudhu'i/metode tematis berdasarkan tema tertentu dari Alquran. Untuk mengkaji konsepkonsep penting yang berhubungan dengan psikologi Islam seperti insan, basyar, nas, Bani Adam, fithrah, ruh, nafs, akal, qalb dan lain-lain metode itu sungguh tept. Caranya ayat Alquran atau Hadis yang terkait dikumpulkan. Hasil inventarisasi dicarikan hubungannya agar masing-masing dapat menjelaskan, lalu disistematisasi menurut disiplin psikologis, hingga didapatkan konklusi yang bernuansa psikologis pula. Keunggulan cara ini adalah selain dapat menampilkan nash secara integral dan komprehensif juga dapat

${ }^{21}$ Muhaimin dan Abdul Mujib, Pemikiran Pendidikan Islam (Bandung: Trigenda Karya, 1993), 6.

${ }^{22}$ Tujuh prinsif berpikir ilmiah-Qurani, yaitu: a). Empiris-metaempiris, b). Rasional-intuitif, c). Objektif-partisipatif, d). Absolutisme moral yang berpijak pada keunikan system, e). Eksplisit mengungkap kemampuan spiritual, f). Aksioma dari ajaran agama, g). Pendekatan holistik menurut model manusia seutuhnya, baru melakukan parsialisasi ke bidang disiplin. (Lihat: Hanna Djumhana Bastaman, Integrasi Psikologi dengan Islam (Yogyakarta: Pustaka Pelajar, 1997), 21.

${ }^{23}$ Malik B. Badri, Dilemma psikologi Muslim, 43.

${ }^{24}$ Abu Husein Muslim ibn al-Hajjaj ibn Muslim, Shabih Muslim (Beirut: Dar al-Fikr, t.th), 219.

25Dawam Rahardjo, Ensiklopedia Al-Quran,: Tafsir Sosial Berdasarkan Konsep-Konsep Kunci (Jakarta: Paramadina, 1996$), 265$.

${ }^{26}$ Langkah-langkah operasional dalam metode pragmatis adalah: a). Penguasaan disiplin ilmu modern dan penguraian kategori, b). Survai disiplin ilmu pengetahuan, c). Penguasaan khazanah Islam tahap analisis, d). Penemuan relevansi Islam yang khas terhadap disiplin ilmu pengetahuan, e). Penilaian kritis terhadap ilmu pengetahuan modern., f). Penilaian kritis terhadap khazanah Islam di masa kini, g). Survai pengetahuan yang dihadapi umat Islam, h). Survai pengetahuan yang dihadapi umat manusia, i). Analisis, kriatif dan sintesis, j). Penuangan kembali disiplin ilmu modern ke dalam kerangka Islam., k). Penyebarluasan ilmu-ilmu yang telah diislamisasi (Lihat: Ismail Raji al-Faruqi, Islamisasi Pengethuan, terj. Anas Wahyuni (Bandung: Pustaka, 1984), 99-115.

${ }^{27}$ Rif at Syauqi Nawawi, Metodologi Psikologi Islami, 138-139. 
menghindari intervensi pemikiran manusia yang berlebihan. Sedang kelemahannya adalah bahwa masing-masimg ayat atau hadis dilatar belakangi oleh konteks dan kondisi yang berbeda.

2) Tafsir Tablili/Tafsir bil Ma'tsur (analisis) yang menafsirkan ayat dengan ayat, riwayat nabi, sahabat dan tabi'in. Dengan metode ini dapat diketahui peristiwa yang terjadi di seputar turunnya wahyu Alquran dan bagaimana situasi sosial-psikologis Rasul dan para sahabat sewaktu turunnya ayat itu. Kelebihan adalah pengkaji dapat memilih ayat atau hadis tertentu yang dianggap representatif saja, sehingga dapat mengkaji secara mendalam. ${ }^{28}$ Kelemahannya bisa terjadi bila pengkaji terlalu jauh dalam analisisnya sehingga keluar dari konteks yang sesungguhnya.

3) Tafsir Maqarin/prosedur perbandingan yaitu memperbandingkan antara ayat satu dengan ayat lain, ayat dengan hadis, hadis dengan ayat dan ayat dengan hadis. Pendapat ulama salaf atau ulama khalaf. Dari sini dapat diketahui adanya ayat yang terminologinya sama tetapi konteksnya berbeda. $^{29}$

4) Tafsir Ijmali/prosedur global dalam mengemukakan penjelasan mengenai ayat-ayat atau hadis yang berkaitan dengan psikologis secara global. Penjelasannya ringkas, bahasa popular dan mudah dimengerti. Prosedur terakhir ini jarang digunakan karena terwakili oleh ketiga prosedur tadi.

b. Metode Ushul Fiqh. Metode ini berfungsi untuk merumuskan kaidah keilmuan dari dalil-dalil Alquran dan Hadis dengan menggunakan penalaran akal yang logis dan rasional. Akal adalah sesuatu yang abstrak dan merupakan aktivitas hati. Kalbu adalah pusat awal kegiatan akal, karena itulah setiap prilaku manusia dihubungkan dengan niat sebagai kehendak yang kuat dan motif yang berasal dari hati. Para sufi yang menekankan pengendalian hati sebagai pemicu setiap perbuatan manusia memusatkan pembinaan akhlak melalui pintu hati ini. Prinsif inilah yang digunakan para pakar hukum Islam untuk mengukur keabsahan sesuatu tingkah laku secara hukum. ${ }^{30}$

Kedua kerangka di atas memberikan tantangan kepada para peneliti, dan pengkaji psikologi Islam untuk menggali khazanah yang dimilikinya. Psikologi Islam dalam membicarakan jiwa sarat nilai yang tidak saja berbicara apa adanya, juga bagaimana seharusnya. Dengan begitu psikologi Islam sarat nilai. Ia terintegrasi dengan teologi dan etika. paradigma dan epistemologi psikologi Islam yang khas mengharuskan psikolog muslim untuk mengkritisi psikologi mereka sendiri.

\section{Metode Penelitian dalam Psikologi Islam}

Suatu penelitian psikologi Islam harus menggunakan teori yang berasal dari pandangan dunia Islam atau setidaknya teori tersebut telah melalui proses islamisasi, yaitu menghubungkan teori Barat dengan ajaranajaran Islam. Bila hanya menggunakan teori Barat penelitian tersebut tidak dianggap sebagai penelitian psikologi Islam sekalipun subyeknya orang Islam.

Di antara jenis penelitian yang biasa dilaksanakan dalam penelitian psikologi dan dianggap sebagai bagian dari metode ilmiah adalah penelitian deskriptif, korelasional, komparatif, eksperimen, Quasieksperimen, studi kasus, etnografi dan lain sebagainya.

1. Metoda deskriptif. Metode deskriptif yang digunakan dalam metode ilmiah adalah observasi, riset korelasi, kuesioner dan wawancara. Pada tingkat intervensi pengamat, observasi terbagi dua. Pertama, obsevasi tanpa intervensi mirip dengan telaah naturalistik, di mana pengamat lebih berperan sebagai pencatat pasif tentang rentetan peristiwa yang terjadi. Kedua, observasi dengan intervensi terbagi dua, yaitu observasi partisipan di mana pengamat turut aktif berperan dalam situasi tingkah laku yang diamati, dan observasi terstruktur di mana pengamat mengadakan intervensi dengan maksud untuk melihat rentetan peristiwa yang terjadi setelah ada intervensi, Eksprerimen lapangan, di mana pengamat memanipulasi satu atau beberapa variabel dalam setting natural pada tingkah laku. Observasi dengan intervensi memungkinkan pembauran dengan

${ }^{28}$ M. Quraish Shihab, Tafsir Al-Quran dengan Metode Maudhu'i Dalam Beberapa Aspek Ilmiah Tentang Al-Quran (Jakarta: Perguruan Tinggi Ilmu Al-Quran, 1983), 23.

${ }^{29}$ M. Quraish Shihab, Tafsir Al-Quran, 38.

${ }^{30}$ Fuad Nashori, Psikologi Islam,150-151. 
nuansa alamiah dengan suatu intervensi dalam upaya menguji suatu teori. Adapun riset korelasi digunakan bila peneliti bertujuan meng-identifikasi hubungan prediktif melalui ukuran kovarian di antara berbagai variabel. Kuesioner/pertanyaan tertulis dan wawancara/pertanyaan langsung digunakan untuk mengumpulkan data dan informasi yang lebih banyak dan mendalam secara langsung. Kelebihan metode ini adalah bahwa jawaban dapat diperoleh dengan cepat dan hasilnya dapat dijadikan dokumen seseorang. Sedang kelemahannya adalah bahwa jawaban terikat pada pertanyaan, sulitnya membuat pertanyaan dengan tingkat relevansi yang tinggi, bisa salah penafsiran, tidak semua pertanyaan sesuai untuk semua orang dan perlunya kerjasama antara penanya dengan responden.

2. Metode eksperimental. Metode eksperimental adalah metode ilmiah yang digunakan untuk melihat sebab akibat dengan prosedur kerja yang berhubungan dengan variabel independen dan variabel dependen. Metode observasi dan eksperimen pernah dilakukan oloeh Malik B. Badri ketika melakukan studi banding antara proses tafakur dengan hukum-hukum alam dalam buku beliau Tafakur Persepektif Psikologi Islam.

3. Metode Fenomenologi. Metode sangat tepat untuk meneliti obyek yang mengarah kepada kondisi dan pengalaman rohani. Penelitian ini terkait dengan peristiwa, kejadian, pengalaman baik dalam perkataan ataupun fakta. Kebenaran fakta bersifat faktis bukan proporsional.

4. Riset Korelasional. Yaitu riset identifikasi hubungan prediktif antara dua variabel, mengungkap perbedaan alat ukur yang dignakan berbentuk alat tes atau skala.

Pada dasarnya, metode-metode yang ditawarkan oleh para ahli di atas, tidak lepas dari pendekatanpendekatan yang pernah dilakukan oleh para pemikir Islam di dalam mengkaji ilmu-ilmu keislaman, termasuk ilmu-ilmu tentang kejiwaan. Secara historis metode-metode yang ditawarkan memiliki dasar yang kuat, baik secara konseptual maupun operasional.

Menurut Hanna Djumhana Bastaman, metode ilmiah yang lazim dipergunakan dalam psikologi (kuantitatif dan kualitatif) dengan teknik-tekniknya seperti wawancara, tes, eksperimen, survei bisa berlaku dalam psikologi Islam, namun ada dua hal yang perlu diperhatikan: Pertama, kesetaraan porsi dan fungsi antara metode kualitatif dan kuantitatif, karena ada gejala dan perilaku manusia serta peristiwa khusus yang dialami secara pribadi, seperti pengalaman keagamaan. Untuk itu metode fenomenologi dapat dipergunakan. Kedua, selain menggunakan metode ilmiah, psikologi Islam mengakui adanya pengetahuan yang didapat melalui ilham dan intuisi dengan melalui ibadah khusyuk seperti tafakekur, shalat Istikharah, shalat tahaijud dan doa. ${ }^{31}$

\section{Penutup}

Pada saat ini, banyak peneliti yang sudah melakukan sesuai dengan model-model penelitian di atas khususnya model pertama dan kedua, padahal kedua model di atas dianggap sebagai model penelitian semi psikologi islami, karena itu masih diperlukan keseriusan para pengkaji psikologi islami untuk menggunakan model ketiga dan keempat yang memang memerlukan usaha yang lebih serius sehingga penelitian psikologi islami yang dicita-citakan bisa terwujud. Akhirnya, untuk membangun sebuah psikologi Islami sebagai sebuahdisiplin keilmuan tentu masih banyak yang harus dilakukan dan diperjuangkan, salah satu cara sederhana yang bisa dilakukan adalah dengan mulai mengadakanpenelitian dengan menggunakan model penelitian seperti yang diajukan diatassehingga psikologi islami yang dicita-citakan dapat terwujud yang pada gilirannya akan menjadi psikologi alternatif yang berfungsi sebagai rahmatan lil'âlamin []

\section{DAFTAR PUSTAKA}

Ancok, Djamaluddin dan Fuad Nashori Suroso. Psikologi Islami, Solusi Islam atas problem-problem Psikologi. Yogyakarta: Pustaka Pelajar, 1994.

Badri, Malik B. Dilema Psikologi Muslim. terj. Siti Zainab Luxfiati. Jakarta: Pustaka Firdaus, 1995. 
Tafakur: Perspektif Psikologi Islam. Terj. Usman Shihab Husnan. Bandung: Remaja Rosdakarya, 1996.

Bastaman, Hanna Djumhana. Integrasi Psikologi dengan Islam. Yogyakarta: Pustaka Pelajar, 1997.

Daradjat, Zakiah. Ilmu Jiwa Agama. Jakarta: Bulan Bintang, 1993.

Al-Faruqi, Ismail Raji, Islamisasi Pengethuan, terj. Anas Wahyuni, Bandung, Pustaka, 1984

Mudjib, Abdul dan Jusuf Mudzakir. Nuansa-Nuansa Psikologi Islam. Jakarta: RajaGrafindo Persada, 2001.

Muhaimin dan Abdul Mujib. Pemikiran Pendidikan Islam. Bandung: Trigenda Karya, 1993.

Nashori, Fuad. Psikologi Islam, Agenda Menuju Aksi. Yogyakarta: Pustaka Pelajar, 1997 Agenda Psikologi Islam, Yogyakarta: Pustaka Pelajar, 2002.

Nawawi, Rifat Syauqi, et. al. Metodologi Psikologi Islami. Yogyakarta: Pustaka Pelajar, 2000.

Purwanto, Yadi. Epistimologi Psikologi Islam. Jakarta: Refika Aditama, 2007.

Sapuri, Rafy. Psikologi Islam, Tuntunan Jiwa Manusia Modern. Jakarta: Rajawali Pers, 2000.

Sardar Z. Menjawab Tantangan Abad 21. Terj. A. E. Priyono \& Ilham Yahya. Bandung: Mizan, 1986.

Shihab, M. Quraish. Tafsir Al-Quran dengan Metode Maudbu'i Dalam Beberapa Aspek Ilmiah Tentang Al-Quran. Jakarta: Perguruan Tinggi Ilmu Al-Quran, 1983.

Syukur, M. Amin Abdullah dan Masyharuddin. Intelektualisme Tasawnf, Studi Intelektualisme Tasawnf Al-Ghazali. Yogyakarta: Pustaka Pelajar, 2002.

Taufiq, Muhammad Izzuddin. Panduan Lengkap dan Praktis Psikologi Islam. Jakarta: Gema Insani, 2006.

Rahardjo, Dawam. Ensiklopedia Al-Quran, Tafsir Sosial Berdasarkan Konsep-Konsep Kunci. Jakarta: Paramadina, 1996. 